Article

\title{
Politics of
}

Imperceptibility:

Philosophy,

Post-Feminism and

New Media Arts 


\section{ABSTRACT}

The essay discusses Deleuze and Guattari's notion of becoming-imperceptible and raises the question to what extent it can be interpreted in terms of feminist politics and seen as a specific strategy for new media arts. Although the notion of becoming-imperceptible was condemned by second wave feminists, recent post-feminists representing the third wave argue not for politics of visibility but for politics of invisibility. Examining the practices of Lithuanian feminist media artists, the essay argues that becoming-imperceptible in new media arts means not an escape from visibility or a drive toward annihilation but a new conceptual strategy: becoming-imperceptible creates the potential for social and political change. This new conceptual strategy can be related to the new quality of the image: in this regard there is a close affinity between Deleuze and Guattari's notion of becoming-imperceptible and the notion of the crystalline image which appears in Deleuze's film theory: both notions engender duration, temporality and qualitative change. Therefore the essay claims that the crystalline image does not represent the world but recreates this world through multiple, changing and virtual images.

\section{POLITICS OF}

\section{IMPERCEPTIBILITY}

The political and social changes after 1990 in Eastern Europe created a special kind of heterotopia and heterochronia: the remnants of the socialist system peacefully coexisted with neoliberal democracy and the capitalist free market, while conservative patriarchal discourses cohabitated with the ideas of tolerance and emancipation coming from the EU. The discourse of gender equality had to compete with the growing Oedipal drive to privatize both property (the notorious process of the privatization of social goods) and desire (the praising of family values and the aesthetization of private life). In this context feminism, which usually has been perceived as a historical process consisting of a first, second and third wave all arrived simultaneously in Eastern Europe and in some sense in competion with each other. Consequently, every feminist philosopher or artist in Eastern Europe had to make a difficult choice between the politics of emancipation, the politics of identity (or visibility), and the politics of imperceptibility (or invisibility). In this paper I will discuss Gilles Deleuze and Félix Guattari's notion of becomingimperceptible and how it can be applied to feminist politics and the work of feminist artists in new media.

The history of feminism has been very closely related to the history of philosophy: the politics of emancipation strives to construct a universal subject that makes 
women equal to men; when this goal is achieved, it is replaced by a need to conceptualize specific gender differences and to argue for a politics of gender identity. However, when a certain identity is defined and recognized, it should be replaced by other forms which are not foreseen or known at the present moment. In other words, once the politics of gender difference or identity had been formulated and conceptualized, it became clear that it was the reverse of the phallocentric ontology: masculine discourse was replaced by écriture féminine, the phallic One was replaced by "sex which is not one" (in Luce Irigaray's words), but the dualistic patterns of thinking behind this opposition remained intact. The second wave feminism elevated the subjected part of the opposition into a dominant position but failed to dismantle the power structure organizing this opposition. Moreover, this structure of power and domination created the eternal cause for feminist struggles and the plea for emancipation. As Jami Weinstein argues, "most advocates of sexual difference as a fundamental ontology would theorize sexual difference into perpetuity and thus establish a basis upon which feminism would always exist" (Weinstein 2008: 25). Following this logic of gender identity or difference, our desire is caught up in a resentment, a reactive and unrealizable thinking.

This is why such theorists as Rosi Braidotti and Elizabeth Grosz argue for undoing gender identity and striving to becoming-imperceptible. Once a feminine identity is conceptualized, it should be replaced by another goal: as Grosz points out, "the future feminine must render itself obsolete or the object of profound and even inhuman (or imperceptible) becomings rather than itself rest on the forms of femininity as they have been represented and idealized in sexual indifference, or within patriarchy as it has existed up to now" (Grosz 2005: 177). So instead of arguing for a politics of recognition and visibility, which is the agenda of identity feminism, Grosz argues for the politics of imperceptibility: "Instead of a politics of recognition, in which subjected groups and minorities strive for a validated and affirmed place in public life, feminist politics should, I believe, now consider the affirmation of a politics of imperceptibility, leaving its traces and effects everywhere but never being able to be identified with a person, a group, or organization. It is not a politics of visibility, of recognition and of self-validation, but a process of self-marking that constitutes oneself in the very model of that which oppresses and opposes the subject. The imperceptible is that which the inhuman musters" (ibid.). Similarly Weinstein, interpreting Grosz, argues that "the ultimate goal of human becoming is becoming imperceptible", though being conscious that "feminists would also be hesitant about, if not completely antagonistic to, the idea that a fully successful feminist strategy is to aim for its own eradication" (Weinstein 2008: 25).

This position raises some difficult questions. What does it mean to become-imperceptible? Are there any politics of becoming-imperceptible? Can this becoming-imperceptible be seen as a visual strategy, and if yes, how can we perceive what is imperceptible? What does becoming-imperceptible mean for feminist politics and can it be seen as a specific feminist strategy? In this ambivalent case we can rely on the Derridian logic of trace, where something is present only in its absence, or the Lacanian logic of symptom, which makes something visible by a negative gesture, by a missing signifier. A similar logic can be found in Peggy Phelan's book Unmarked: the Politics of Performance where she argues, that "there is real power in remaining unmarked; and there are serious limitations to visual representation as a political goal" (Phelan 1996: 6). Borrowing her logic from Freud and Lacan, Phelan formulates what she calls the unmarked, which "shows itself through the negative and through disappearance". "I am speaking here of an active vanishing, a deliberate and conscious refusal to take the payoff of visibility. For the moment, active disappearance usually requires at least some recognition of what and who is not there to be effective" (Phelan 1996: 19; my emphasis). 


\section{BECOMING-IMPERCEPTIBLE IN DELEUZE AND GUATTARI}

The politics of imperceptibility has a certain background in Gilles Deleuze and Félix Guattari's philosophy. In A Thousand Plateaus Deleuze and Guattari formulate the notion of becoming which they oppose to the traditional notion of subjectivity. By contrast to the metaphysical notion of subjectivity which is based on one or another identity, Deleuze and Guattari see subjectivity as a permanent process of becoming. Deleuze and Guattari refer to different kinds of becoming - becoming-woman, becoming-animal, becoming-music, becoming-imperceptible. It is important to stress that becoming is, by definition, molecular. Contrary to molar structures, which define and divide separate entities, molecular becoming refers to change, transformation, and reorganization. Deleuze and Guattari speak about three types of "lines" that define the relationship between the subject and society. The first type of line is based on a rigid segmentarity and defines the relations between sexes, races, classes: man - woman, adult - child, human - animal. The second type of line traverses these rigid distinctions - these are molecular becomings. The third type of line is even more strange: "[A]s if something carried us away, across our segments, but also across our thresholds, towards a destination which is unknown, not foreseeable, not pre-existent" (Deleuze, Parnet 2006: 94). This is the line of flight which takes us to something unforeseeable. These three types of line are immanent, caught up in one another. For example, if we try to rethink these types of line in terms of a gender dimension, we can say that the opposition man - woman describes molar identities, while becoming-woman is a molecular process which traverses gender distinctions. Molecular becoming in its turn can move into a different direction: "sexuality proceeds by way of the becoming-woman of the man and the becoming-animal of the human: an emission of particles" (Deleuze, Guattari 2004b: 307). Deleuze and Guattari point out that becoming has neither beginning, nor end - it is always in the middle: "becoming is to extract particles between which one establishes the relations of movement and rest, speed and slowness that are closest to what one is becoming, and through which one becomes. This is the sense in which becoming is the process of desire" (Deleuze, Guattari 2004b: 300-301).

Although Deleuze and Guattari argue for different types of becoming, any becoming begins with and passes through becoming-woman: "It is the key to all the other becomings" (Deleuze, Guattari 2004b: 306). This means not imitating a woman or becoming like a woman but "emitting particles that enter the relation of movement and rest, or the zone of proximity, of a microfemininity, in other words, that produce in us a molecular woman" (Deleuze, Guattari 2004b: 304). In this sense Deleuze and Guattari see a feminine identity, or what they call "a molar woman", as an obstacle to their project of becoming. They point out that it is "indispensable for women to conduct a molar politics, with a view to winning back their own organism, their own history, their own subjectivity... But it's dangerous to confine oneself to such a subject, which does not function without drying up a spring or stopping a flow" (Deleuze, Guattari 2004b: 304). That means that the process of becoming-woman should not imitate a molar woman but has to create what Deleuze and Guattari call a "politics of molecular woman". Such a politics withdraws from a specific feminine subjectivity and merges this subjectivity into impersonal, multiple, molecular flow. By contrast, the attempt to recreate feminine identity would mean the return to the binary molar forms and rigid segmentarity.

Deleuze and Guattari's notion of becoming-woman provoked radical feminist reactions. In 1994, both Rosi Braidotti and Elizabeth Grosz published books in which they closely examined Deleuze and Guattari's philosophy and its implications for feminist thought. Braidotti in Nomadic Subjects was quite critical about the implications of Deleuze and Guattari's philosophy for feminism. On the one hand, 
she interpreted the theory of becoming as a conceptual possibility engendering new forms of feminine subjectivity; on the other hand, she was wondering if this theory is not another male fantasy, seeking to recuperate specific feminist territories. Braidotti points out that the Deleuzian theory of becoming is very ambivalent, because, on the one hand, the becoming-woman is posited as a potentiality of the new philosophical subjectivity, and, on the other hand, feminists are conscious that not all the forms of this process of becoming are equivalent. Thus, "the becoming-woman is a privileged position for the minority-consciousness of all" and in this way women are again positioned as the privileged figure of otherness (Braidotti 1994: 114).

Braidotti also seemed to be quite unconvinced by Deleuze and Guattari's call for the dissolution of feminine subjectivity and sexuality into an impersonal, multiple, molecular flow. For example, Braidotti argued, that "one cannot deconstruct a subjectivity one has never controlled". Braidotti pointed out that self-determination is the first step of any process of deconstruction and claimed that "Deleuze gets caught in the contradiction of postulating a general 'becoming-woman' that fails to take into account the historical and epistemological specificity of the female feminist stand point" (Braidotti 1994: 117). She also pointed out that a theory of difference that fails to define sexual difference left her as a feminist philosopher in a state of sceptical perplexity (ibid.). Similarly Grosz in Volatile Bodies argued that "what becoming-woman means or entails for men is different than for women. For men, it implies a de- and restructuring of male sexuality, (...) bringing into play the microfemininities of behaviors, the particles of another sexuality, or many sexualities... But exactly what this means for women remains disturbingly unclear" (Grosz 1994: 177). Like Braidotti, Grosz was concerned that the process of becomingwoman actually led to the abandoning of the very struggles by which feminists had sought to create new social places and values for women (ibid.). To summarize, feminist thinkers were quite critical about Deleuze and Guattari's theory because they assumed that a feminist project could not be conceptualized without one or another form of feminine identity. But for Deleuze and Guattari it is precisely identity, or what they call stratification (the division between classes, races and sexes) that creates the conditions of domination and repression. As far as feminist theory cannot conceptually reject the standard forms of identity, it still operates within the framework of molar stratification.

However, in their recent works, both Braidotti and Grosz have reconsidered Deleuze and Guattari's theory in a much more positive way. For example, in Metamorphoses (2002) and Transpositions (2006) Braidotti, even repeating all her reservations expressed in Nomadic Subjects, is convinced that the theory of becoming opens "alternative patterns of desire". Following the Deleuzian critique of psychoanalysis, Braidotti points out that one of the most important implications of this theory is the new interpretation of desire: desire is defined not in terms of negativity and lack but in terms of productive and creative forces. Desire is not repressed but produced and expressed in new collective assemblages: "desire is for me a material and socially enacted arrangement of conditions that allow for the actualization (that is, the immanent realization) of the affirmative mode of becoming" (Braidotti 2002: 99). Another important point is that becoming presupposes temporality, duration, endurance and has the power to enact a qualitative change: "Temporally speaking, a body is a portion of living memory that endures by undergoing constant internal modifications following the encounter with other bodies and forces" (ibid.). Similarly, Grosz points out that Deleuzian notions of becoming, duration and virtuality are crucial in trying to conceptualize a change and to introduce this change into our social and political reality: "This understanding of virtuality as the impetus for incipient action is itself a dynamising concept, one which may serve feminist, anti-racist and other 
political movements by making clear that there is always a leap, an unexpectedness that the new brings with it, and that it is the goal of politics to initiate such leaps" (Grosz 2000: 228-229). In her book Time Travels:

Feminism, Nature, Power Grosz is more and more critical about the issues of agency and identity and argues for a Deleuzian quest for the impersonal and inhuman: "I don't claim that agency and identity are impossible, but rather that subjectivity, sexuality, intimate social relations are in part structured not only by institutions and social networks but also by impersonal or prepersonal, subhuman, or inhuman forces..." (Grosz 2005: 6).

These impersonal or inhuman forces are the most complicated issue in Deleuze and Guattari's philosophy. Deleuze and Guattari clearly state that becomingwoman is only the first stage in the general process of becoming, which should move toward becoming-imperceptible. And they ask, "But what does becomingimperceptible signify, coming at the end of all the molecular becomings that begin with becoming-woman?" As Deleuze and Guattari explain: "Becoming-imperceptible means many things. What is the relation between the (anorganic) imperceptible, the (asignifying) indiscernible, and the (asubjective) impersonal?" (Deleuze, Guattari 2004b: 308). The quest for the imperceptible, the indiscernible, and the impersonal recalls the three characteristics defining the notion of the Body without Organs: it is the deconstruction of organism, signification and subjectivity. We can presume that to become imperceptible means to dis-organize the body as an organism, to dismantle the system of signification and interpretation, to erase the subject and subjectivity. Deleuze and Guattari argue that becoming-imperceptible leads to a reduction of oneself: "to reduce oneself to an abstract line, a trait, in order to find one's zone of indiscernibility with other traits, and in this way enter the haecceity and impersonality of the creator" (Deleuze, Guattari 2004b: 309). Becoming-imperceptible is the process of the dissolution of the subject into haecceities: haecceity is a term taken from scholastic philosophy which is sometimes rendered as "thisness", which means individuation without subjectivity. It is precisely these individuations without subjectivity, which create the spontaneous energy of every process of becoming: becomingimperceptible leads not toward annihilation or nothingness but toward making the world or becoming-world.

In her article "The Ethics of BecomingImperceptible" Braidotti points out two important characteristics of becoming: its temporality, duration, endurance and the capacity to form assemblages. This means that becoming-imperceptible moves not towards self-annihilation but is the openness towards temporality and change. Someone having this or that identity can transform themself into another over time and experience a qualitative change. This change emerges through agency (agencement), producing different social, political, and affective connections. As Braidotti points out, "A subject thus constituted inhabits a time that is the active tense of continuous 'becoming.' Deleuze defines the latter with reference to Bergson's concept of 'duration', thus proposing the notion of the subject as an entity that lasts, that is to say that endures sustainable changes and transformation and enacts them around him/herself in a community or collectivity" (Braidotti 2006: 135). It is precisely this potentiality of change which makes the theory of becoming so important not only for post-feminism but also for new media arts.

\section{BECOMING-IMPERCEPTIBLE IN NEW MEDIA ARTS}

The notions of becoming and duration are crucial in discussing the new media arts. While more conventional art forms rely on the representation of already existing time and space relationships, by contrast, the new media arts constitute the temporality or duration of time. The passing of time or duration creates the conditions of corporeal and simultaneously of mental change which can be rethought as a political issue. Following Deleuze and Guattari, we can 
ask what a body can do, what it is capable of, what affects it can produce or perceive? How can these changes and transformations effect or not effect power relationships? Having these questions in mind, let's discuss some specific examples of Lithuanian new media art.

Egle Rakauskaitè was one of the first artists trying to examine the limits of the body and its interface with different materials and surroundings. In creating her videos and performances Rakauskaite uses different organic substances - human hair, dried petals, chocolate, honey, fat - which displace or even question the anthropomorphic forms of subjectivity. In some artworks these materials acquire their own life creating haecceities - individuations without subjectivities. For example, a human hair continues its existence in the form of a net, which traces the contours of the Vilnius Ghetto, which disappeared in 1943 (Be kaltès kaltiems. Tinklas / For Guilty without Guilt. Net, 1995). But the most famous are her videos featuring the interface between the body, different substances and temporality. In the video performance entitled In Honey (Meduje, 1996) the artist was trying to submerge her body in a honey substance but it pushed the body to the surface as if in an act of repulsion. Another video In Fat (Taukuose, 1997) shows the artist submerging her body in warm fat: while warm the fat was transparent but by getting cooler it became opaque and buried her into a white sarcophagus. The performance In Fat was filmed with three cameras and screened on three monitors, which were turned away from the spectator in such a way that one could see not the image itself, but only the reflection of the image, mirrored from the glass surface. In this way the gaze of the spectator was interrupted and broken up, as if trying to evade the standardized types of representation. At the same time the fat, by getting cooler became opaque and

For more information about Eglè Rakauskaite’s work see http://www.culturebase.net/artist.php?329 and also http://courses.washington.edu/femart/ final_project/wordpress/egle-rakauskaite/ (26 September 2013). gradually concealed the artist's body from the spectators gaze, making it almost invisible. In this sense, the process of letting the fat get cool and opaque can be interpreted as a refusal to pose for the consuming gaze of the Other. At the same time it is a refusal to present the body in terms of social or political agency. This body recalls the Body without Organs, the return to the primary, undifferentiated, whole body. As Grosz puts it, "Unlike psychoanalysis, (...) the Body without Organs invokes a conception of the body that is disinvested of fantasy, images, projections, representations, a body without a psychical or secret interior, without internal cohesion and latent significance" (Grosz 1994: 169). For Deleuze and Guattari the Body without Organs means the possibility of the disorganized body, which is "free" from any sexual, visual, social or political appropriations. "The Body without Organs is what remains when you take everything away. What you take away is precisely the phantasy, and signifiances and subjectifications as a whole" (Deleuze, Guattari 2004b: 168). In this sense the artistic performance by Rakauskaite changes the gender scenario into which the body is inscribed and transforms it into an impersonal or even inhuman material on which new signs and imprintings could be imposed. We can conclude that the performance we see blocks the play of imagination, "unplugs" the body from the conventional scenario and transforms it into impersonal material. Unfortunately, Rakauskaite’s performance does not reveal how this impersonal material can be rearranged into new social or political assemblages.

Kristina Inčiūraitè ${ }^{2}$, another Lithuanian female artist who regularly deals with gender issues, provides another strategy of becoming-imperceptible, because she works not with bodies or substances but with mental images. Inčiūraitè's videos usually depict female characters in their specific social environment but the most important thing is that these female fig-

For more information about Kristina Inčiūraite’s work see her website: http://www.inciuraite.lt/ (26 September 2013). 
ures are not visible on the screen. In other words, the visible and perceptible dimension is suspended in order to demonstrate mental connections between what is visible and what remains invisible. This invisibility prompts the spectator to think about the social and political status of those who are missing in the screen.

These intellectual links between what is visible and what remains invisible constructs the structure of Inčiūraitè's videos. For example, Bathhouse (Pirtis, 2003; 1, 2) is constructed in such a way that it makes a contrast between the virtual image that inspired the story, and the actual perception, which in its turn is split between visible and audible perception. The video was inspired by Gustav Machatý's film Ecstasy (Extase, 1933), starring the Austrian actress known as Hedy Lamarr. In this film the young actress performed naked in a swimming scene that lasted 10 minutes. This shocked European society as well as her husband, who unsuccessfully tried to purchase all existing copies of Ecstasy. The video by Inčiurraite, by contrast, depicts the bathhouse in Innsbruck that was opened in 1927. The video captures the empty premises of the bathhouse. The visual images are accompanied by interviews with students of the Innsbruck school of actors. They discuss such questions as performing and nudity, the relationship between erotic and shame. Although the interview is focused on the naked body and eroticism, the young female narrators are not visible, only imagined. What we actually see are the images of the bathhouse which traditionally is conceived as a place where nude bodies are exposed.

So the video creates imagery that functions on three different levels: the first level is a virtual image of Hedy Lamarr performing naked in a swimming scene, which engenders a mainstream representation of a naked female body; the second level is an actual narrative by young female actresses, discussing eroticism and subjective bodily experience, although the actresses themselves remain invisible; the third level is the actual perception of the bathhouse images that show the traditional place where naked bodies are exposed without actually showing any bodies. This indiscernibility between the virtual imagery of Ecstasy and the actual experience of the stories of young actresses, between the real of visible heacceities or "thisness" of bathhouse and the imaginary bodies creates what Deleuze calls the crystalline image. As Deleuze points out in Cinema 2: The TimeImage, the crystalline image is "the point of indiscernibility of the two distinct images, the actual and the virtual, while what we see in the crystal is time itself, a bit of time in the pure state" (Deleuze 2008: 79). The crystalline image has a unique power to disorganize a mainstream, or as Deleuze calls it, "organic" image, which relies on "natural" reference between the image and the thing. By contrast, the crystalline image does not represent a thing. As Rodowick points out, "Crystalline description is provisional and contingent. It replaces the object, continually 'erasing' it and creating it anew, giving way to other equally adequate descriptions, which may modify or contradict the ones preceding it. (...) Each time a virtual image is called up in relation to an actual description, the object depicted is de-formed and created anew, widening and deepening the mental picture it inspires" (Rodowick 1997: 90). In this specific example the crystalline image deconstructs the mainstream representation of the female body by dissolving it into different layers: the virtual and the actual, the real and the imaginary, the visual and the audible. This crystalline image dismantles the habitual visual scenario according to which woman is represented as an erotic object: instead of scopic visual pleasure we are confronted with haecceities - individuations without subjectivities - the images of water and ceramic tiles.

Another video by Inčiūraitè, Lakes (Ežerai, 2004; 3, 4), has a similar crystalline structure. The video is projected on two screens and presents two narratives: the first features the Lithuanian actress Vaiva Mainelyte who narrates about her experience performing in a famous erotic scene in Arūnas Žebriūnas' film The Devil's Bride 
(Velnio nuotaka, 1974), in which the half naked actress was swimming in the lake. The second narrative features Inčiūraitè's mother telling about the lakes in her neighbourhood. Both women remain invisible, we hear only their voices and their stories which are accompanied by the images of frozen lakes. The narration of Vaiva Mainelyte refers to the famous erotic scene which is virtually present in our visual memory. This virtual recollection contrasts with her subjective experience of shooting the scene: her main impression of the scene is the sense of coldness; visually this impression is accompanied by the actual images of frozen lakes. Here we see the multiple or crystalline structure of video imagery: first we have the virtual recollection of a "hot" erotic scene, which is accompanied by actual narration (the feeling of coldness) and actual images of frozen lakes. This multilayered structure deconstructs or decomposes the myth of the "naturally" sexed bodies. We can even say that sexual fantasy here is literally frozen because our perception is not supported by standard visual codes and roles.

This specific visual strategy by Inčiūraitè's videos can be related to Deleuze and Guattari's idea that subjectivity, desire and sexuality should be detached from its anthropomorphic forms (Deleuze, Guattari 2004a:324-325) and move toward becoming-imperceptible. Deleuze and Guattari see this move as the only way to evade the molar forms of subjectivity and sexuality and to subvert the dominant regimes of patriarchy. In this sense we can speak about the politics of imperceptibility, which questions the dominant scopic regimes not by demands to make one or another social group visible but by following the path of becoming-imperceptible. Here again all the features mentioned by Deleuze and Guattari become relevant: to become anorganic or imperceptible, to become the asignifying or indiscernible, and to become asubjective or impersonal. All three features are at work in Inčiūraitè's videos: first there is the dissolution or evacuation of the body, the "organic" body, which is the "natural cause" of representation. When the body is dismantled or lost, representation itself loses its "natural" referential anchor. Second, on the level of signification and interpretation, we enter a zone of indiscernibility where it is impossible to decide between the virtual and the actual, between the real and the imaginary, the visible and the audible. And third, these videos create an impersonal or inhuman perspective where desire is pinned up not to the human subject but to different individualities or heacceities - water, coldness, and duration - the passing of time.

Another video by Inčiūraite, Dance (Šokis, 2006), also reflects on the theme of the representation of the body and sexuality. The artist recycles a fragment from Arūnas Žebriūnas' film The Last Day of Holidays (Paskutine atostogu diena, 1964) which shows a girl dancing on the beach. Inčiurraite asked the students of Vilnius Balys Dvarionas Musical School - who are of the same age as the girl in the film - to create a sound track for the film excerpt. As a result of this collaboration we see a video loop which presents the same film fragment with five different musical interpretations: every repetition rewrites this "primal scene" anew. Referring to Deleuze's seminal book Difference and Repetition we can say that every repetition in a sense deconstructs the primary status of this "primal scene" and makes us think to what extent the representation and sexualization of the child's body is determined by ideological cliché. The dance, which seemed to be absolutely neutral in 1964 now enters into different musical, discursive and sexual interpretations. These competing interpretations reveal that every society creates their own images of sexuality and shapes the bodies according to their patterns of discourse.

The last example reexamines not only gender issues but also the temporal nature of video media itself. In Inčiūraitè's Fall (Žlugimas, 2005; 5, 6) we see the empty spaces of a famous Ozas cinema theatre together with an old video rental collection. A woman's voice tells us that the cinema is living its last days because in contem- 
porary society there is no interest in old films in video format. This "fabulation" is accompanied by the acoustic remnants of the sound track from Anthony Mann's film The Fall of the Roman Empire (1964): Sophia Loren's voice cries for the empire that does not exist anymore. This cry conveys several meanings: literally it is a cry for the Roman empire, but indirectly it is also a cry for the Soviet empire and the rigid but at the same time clear social segmentarity it had established. Simultaneously, it is a reflection on the temporal nature of media forms which are vanishing from our lives together with old cultural values and codes. The sexual exaltation of Sophia Loren's voice is replaced by the monotonous "fabulation" of the female cinema employee; her story is accompanied by the empty spaces of the cinema theatre interiors. So at the same time we can speak not only about the fall of empire(s) but also about the fall of sexual representation, which in Inčiūraitë's films has a political significance: when woman rejects her role of sexual fetish she starts acting as social agent. The emptying of visual space or a certain politics of becomingimperceptible deconstructs the patterns of representation which are necessarily the patterns of molar stratification: the empty crystalline image opens a space for becoming, transformation and change.

This act of becoming-imperceptible establishes a new kind of visual regime based not on "organic" or "natural" perception but on philosophical recollection and reflection. Deleuze makes several points in defining the contrast between the organic and the crystalline regimes. The first point relates to description: the organic regime describes the object as if it exists independently of the camera, whereas the crystalline description "stands for its object, replaces it, both creates and erases it (...) and constantly gives way to other descriptions which contradict, displace, or modify the preceding ones. It is now the description itself which constitutes the sole decomposed and multiplied object" (Deleuze 2008: 122). The second point concerns the relation between the real and the imaginary: in the organic regime the real and the imaginary are recognizable and distinguishable, whereas in the crystalline regime the two modes of existence form a circuit, "where the real and the imaginary, the actual and the virtual, chase after each other, exchange their roles and become indiscernible" (Deleuze 2008: 123). The third point concerns the narration and its relation to truth: the organic regime creates a narration following a sensory-motor schemata. In this sense it is always a truthful narration, even if it relates to fiction. By contrast, the crystalline description rejects the sensory-motor schemata and gives way to pure optical and sound situations (Deleuze 2008: 124). The narration ceases to be truthful and becomes falsifying, in other words, it opens the "powers of the false".

The "powers of the false" do not mean pure appearance or even a lie here; the "powers of the false" open the way to becoming, "which constitutes series or degrees, which crosses limits, carries out metamorphoses, and develops along its whole path an act of legend, of story-telling. Beyond the true or the false, becoming as power of the false" (Deleuze 2008: 264). In this sense, we can see a close affinity between the Deleuzian notion of becomingimperceptible and the notion of the crystalline image which appears in Deleuze's film theory: both notions are based on duration, temporality and qualitative change. The crystalline image does not represent the world but recreates this world through multiple, changing and virtual images. Such a visual strategy suspends the spectator in a regime of uncertainty because every image becomes what probability physics calls a "bifurcation point", where it is impossible to predict in advance which direction the change will take. Rodowick compares Deleuzian film theory with that of Ilya Prigogine's ideas, asserting that the bifurcation point can define an equal chance in the evolution of physical systems: "Either the system disintegrates into chaos, or it makes an unforeseen and unpredictable leap to a new, more complex, and different order" (Rodowick 1997: 16). 
To summarize, becoming-imperceptible means not an escape from visibility or a drive toward annihilation but a new conceptual strategy for new media arts: becoming-imperceptible opens the potential of the unforeseen and the unpredictable and in this sense creates the conditions for social and political change. Of course, some feminist thinkers and artists might have reservations about this strategy, saying that becoming-imperceptible leads to abandoning the feminist struggles for recognition and visibility. But the crucial thing here is to detach oneself from the old logic of molar stratification and move toward the flux of molecular becoming that can engender bodily modifications, political changes and artistic innovations. Deleuze was very conscious about this when he pointed out that "female authors, female directors, do not owe their importance to a militant feminism. What is more important is the way they have produced innovations in this cinema of bodies, as if women had to conquer the source of their own attitudes and the temporality which corresponds to them as individual or common gest" (Deleuze 2008: 189). In this sense, the becomingimperceptible can be seen as a practice of experimentation working on several levels: first, it is an attempt to abandon the anthropomorphic forms and defined gender identities and replace them with molecular transformations; second, it is an attempt to abandon the old forms of representation and open the space for the crystalline regime of virtual images, creating and recreating the world. Even if such a politics of becoming-imperceptible does not belong to a safety zone and is not necessarily a successful visual strategy, it can equally disintegrate into chaos or it can make an unforeseen and unpredictable leap to a new social and political order.

\section{REFERENCES}

Braidotti, R. 1994. Nomadic Subjects: Embodiment and Sexual Difference in Contemporary Feminist Theory. New York: Columbia University Press.

Braidotti, R. 2005. Metamorphoses: Towards a

Materialist Theory of Becoming. Cambridge: Polity Press. Braidotti, R. 2006. Transpositions: On Nomadic Ethics. Cambridge: Polity Press.

Braidotti, R. 2006. 'The ethics of becoming-imperceptible."' - C. V. Boundas (ed.), Deleuze and Philosophy. Edinburgh: Edinburgh University Press, 133-159. Deleuze, G. 2008. Cinema 2: The Time-Image. Trans. H. Tomlinson; R. Galeta. London, New York: Continuum. Deleuze, G.; Guattari, F. 2004a. Anti-Oedipus.

Capitalism and Schizophrenia. Trans. R. Hurley,; M. Seem; H. R. Lane. London, New York: Continuum. Deleuze, G.; Guattari. F. 2004b. A Thousand Plateaus: Capitalism and Schizophrenia. Trans. B. Massumi. London, New York: Continuum.

Deleuze, G.; Parnet, C. 2006. Dialogues II. Trans. H. Tomlinson, B. Habberjam. New York, London: Continuum.

Grosz, E. 1994. Volatile Bodies: Toward a Corporeal Feminism. Bloomington, Indianapolis: Indiana University Press.

Grosz, E. 2000. 'Deleuze's Bergson: Duration, the virtual and a politics of the future'. -I. Buchanan, C. Colebrook (eds.), Deleuze and Feminist Theory. Edinburgh:

Edinburgh University Press, 214-234.

Grosz, E. 2005. Time Travels: Feminism, Nature, Power. Crow's Nest: Allen and Unwin.

Phelan, P. 1996. Unmarked: The Politics of Performance. London, New York: Routledge.

Rodowick, D. N. 1997. Gilles Deleuze's Time Machine. Durham and London: Duke University Press. Weinstein, J. 2008. 'Introduction part II'. - C. Colebrook, J. Weinstein (eds.), Deleuze and Gender. Deleuze Studies, vol. 2. Edinburgh: Edinburgh University Press, 20-33. 


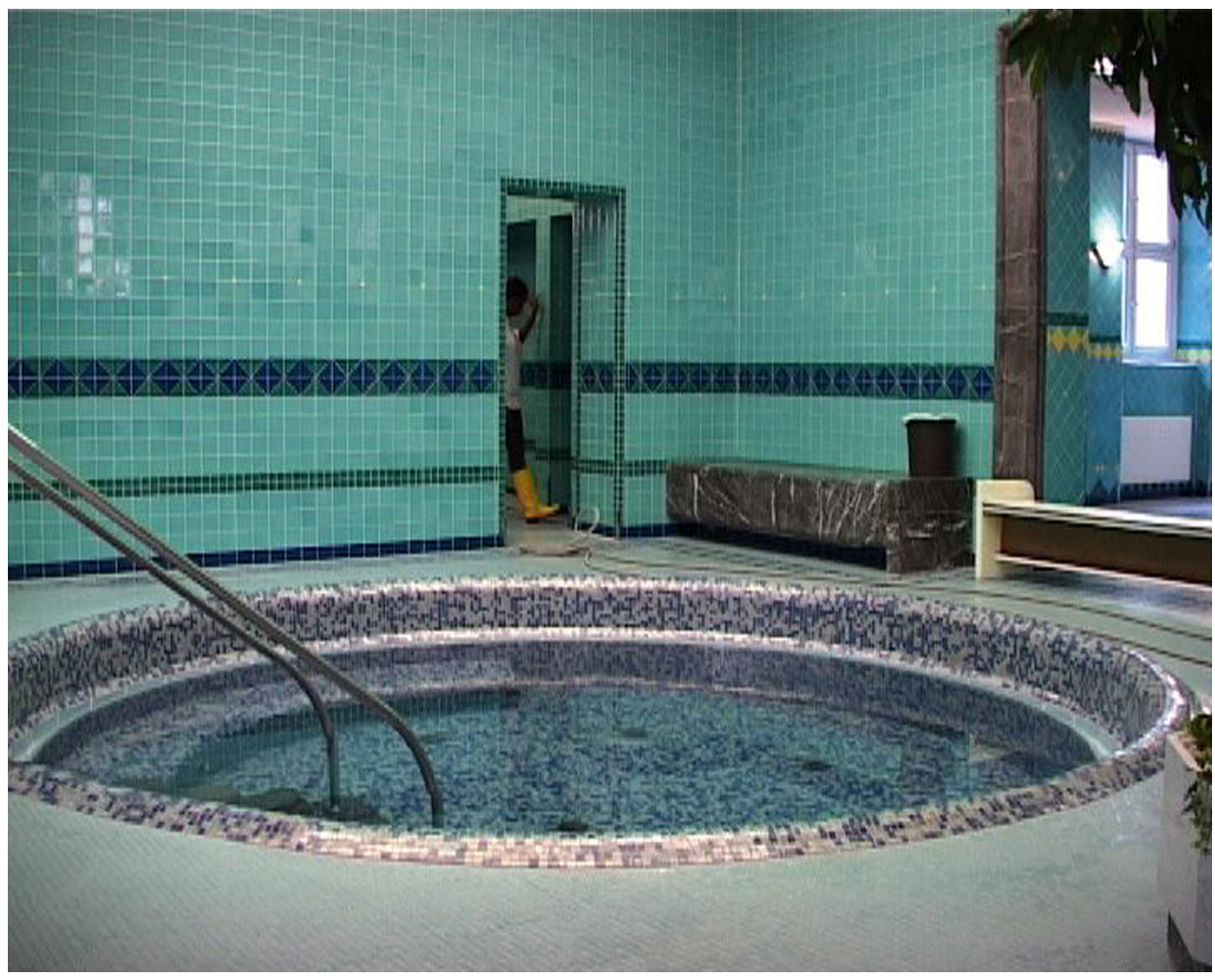

1

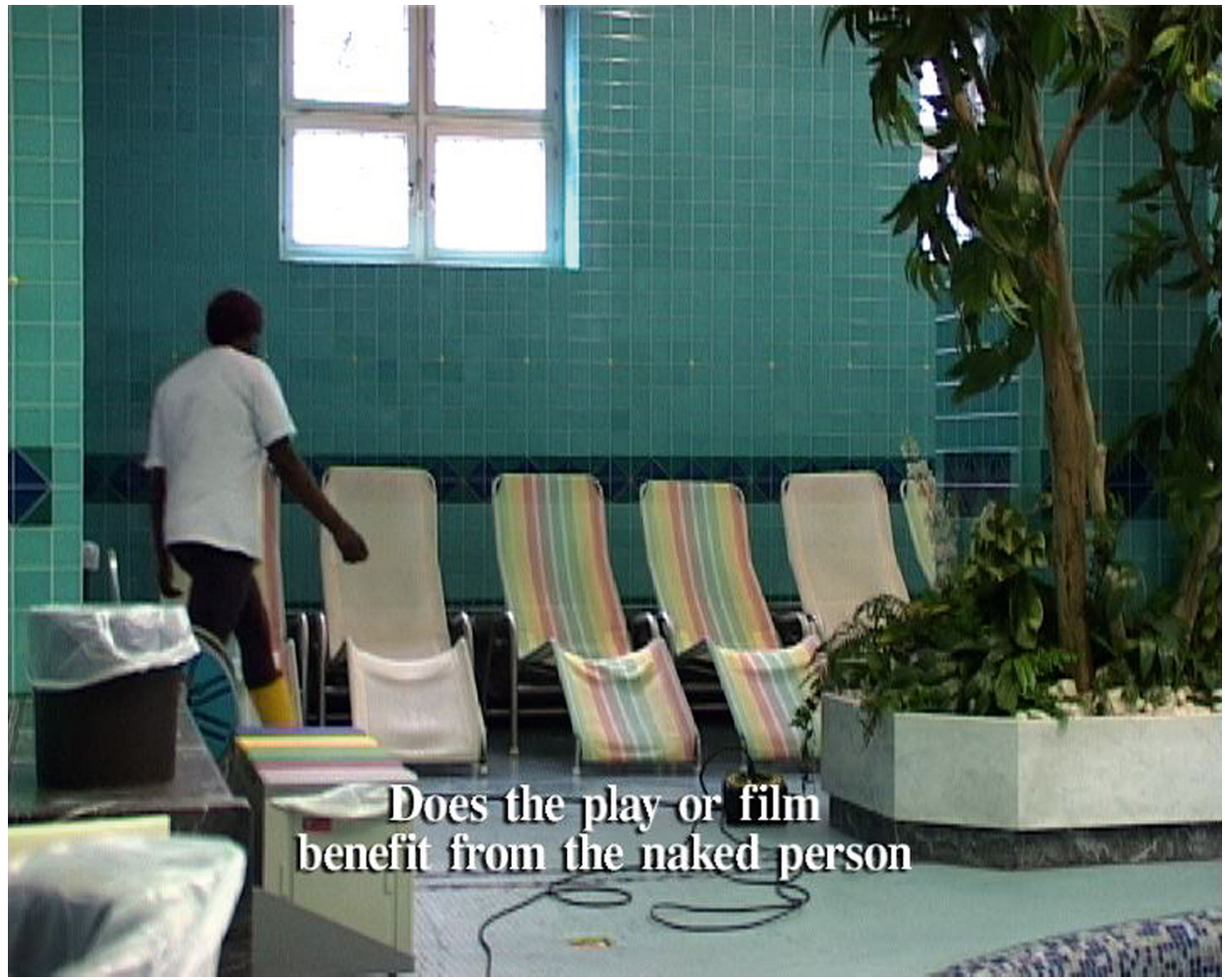




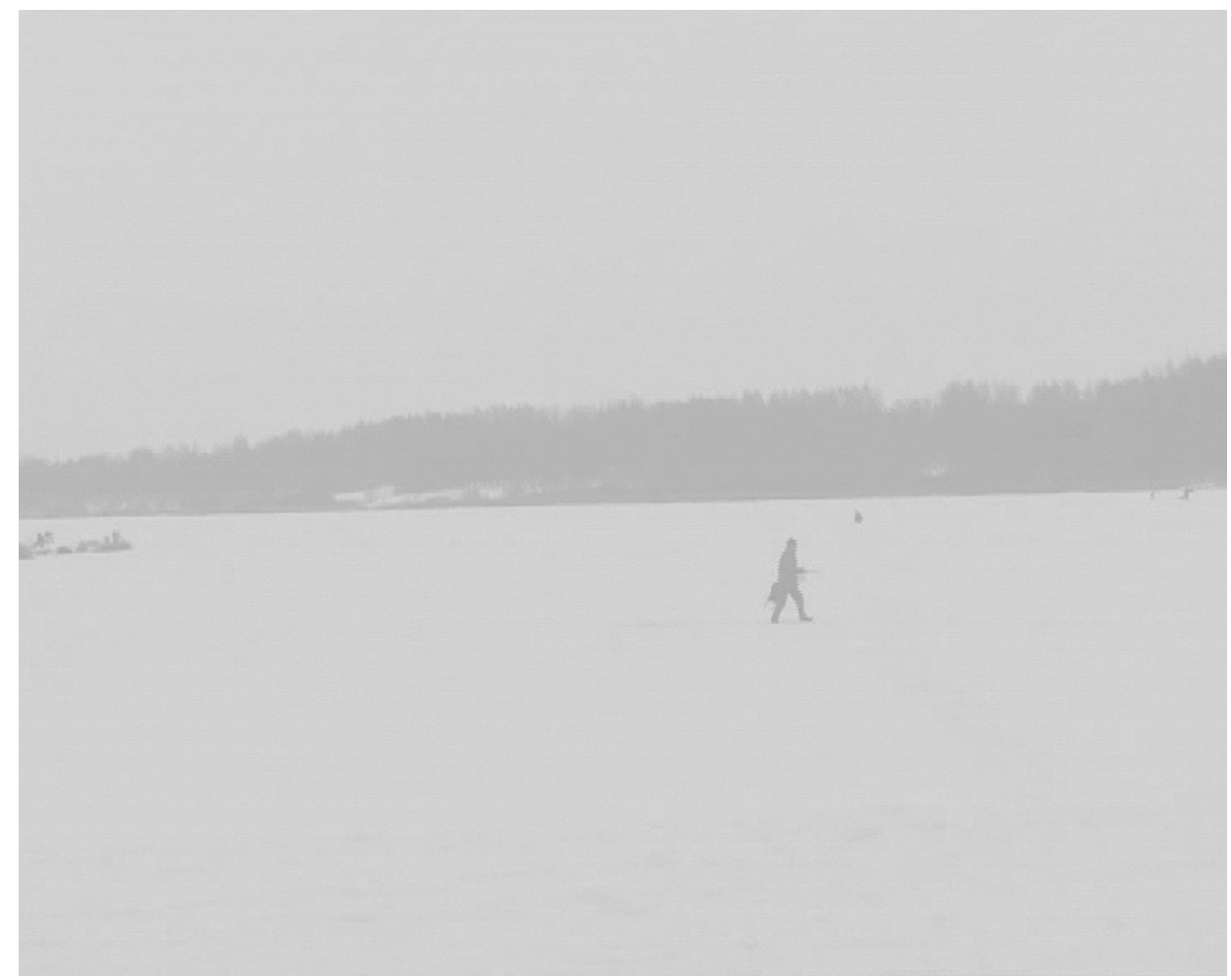

3

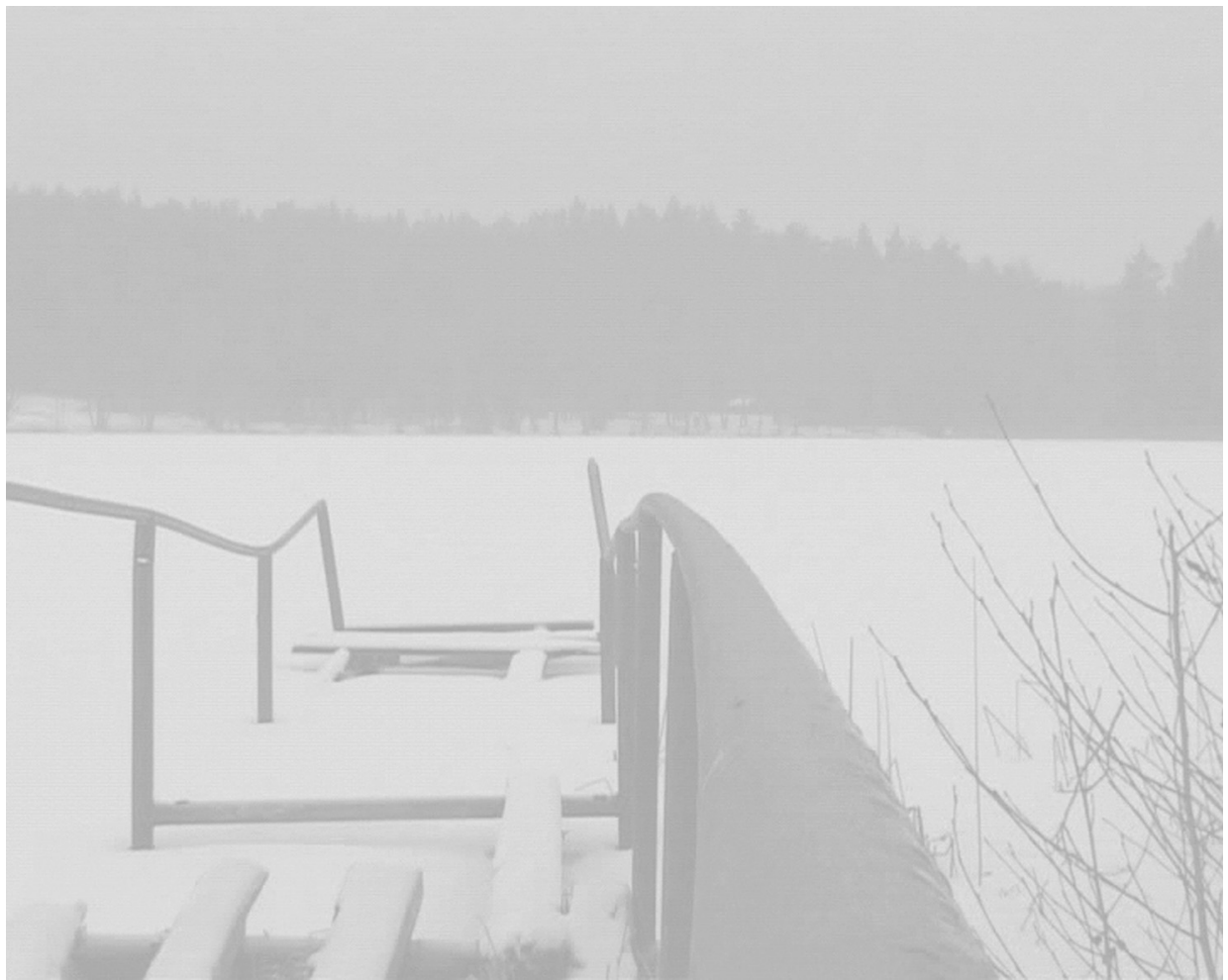

4 
BALTIC SCREEN MEDIA REVIEW 2013 / VOLUME 1 / ARTICLE

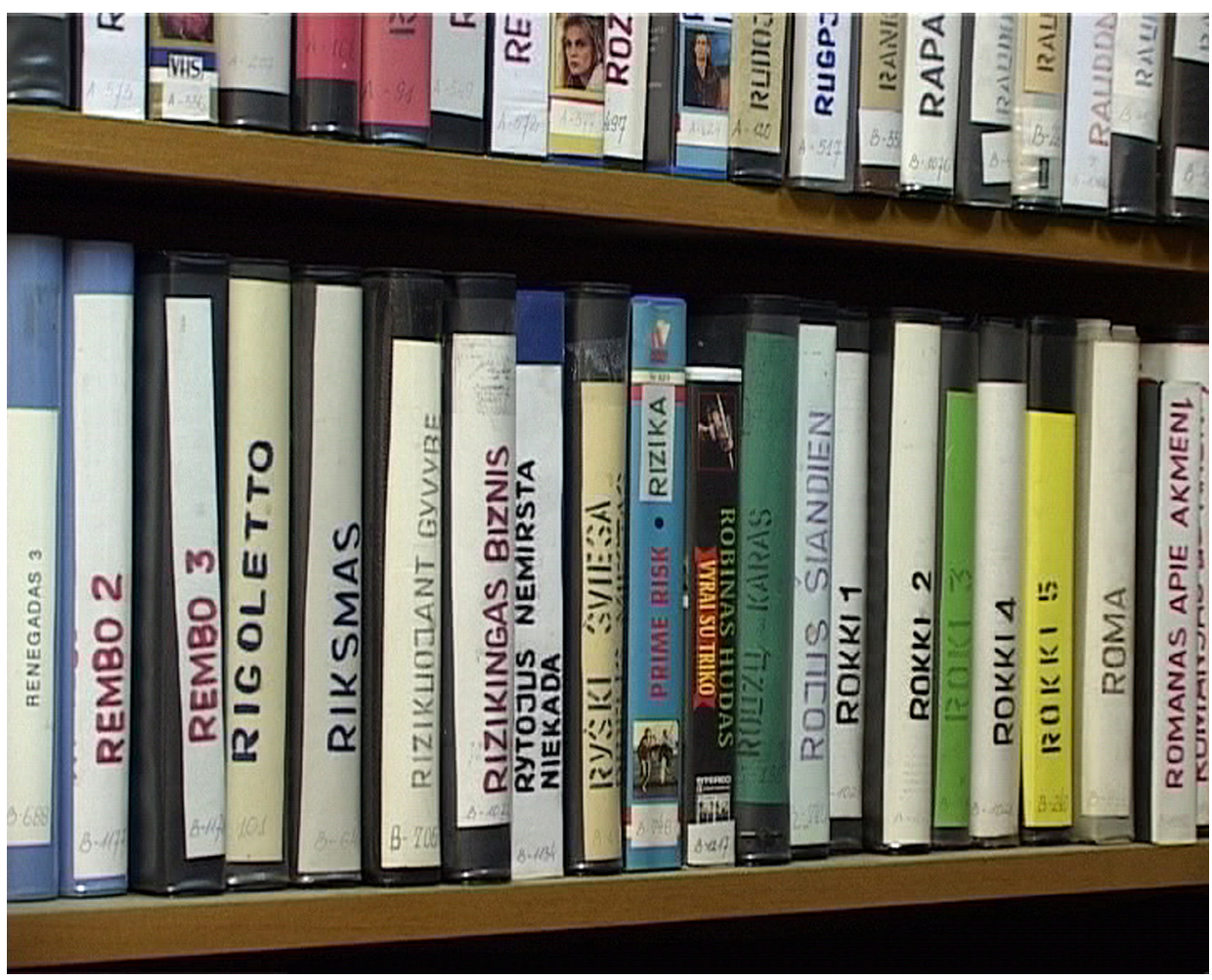

5

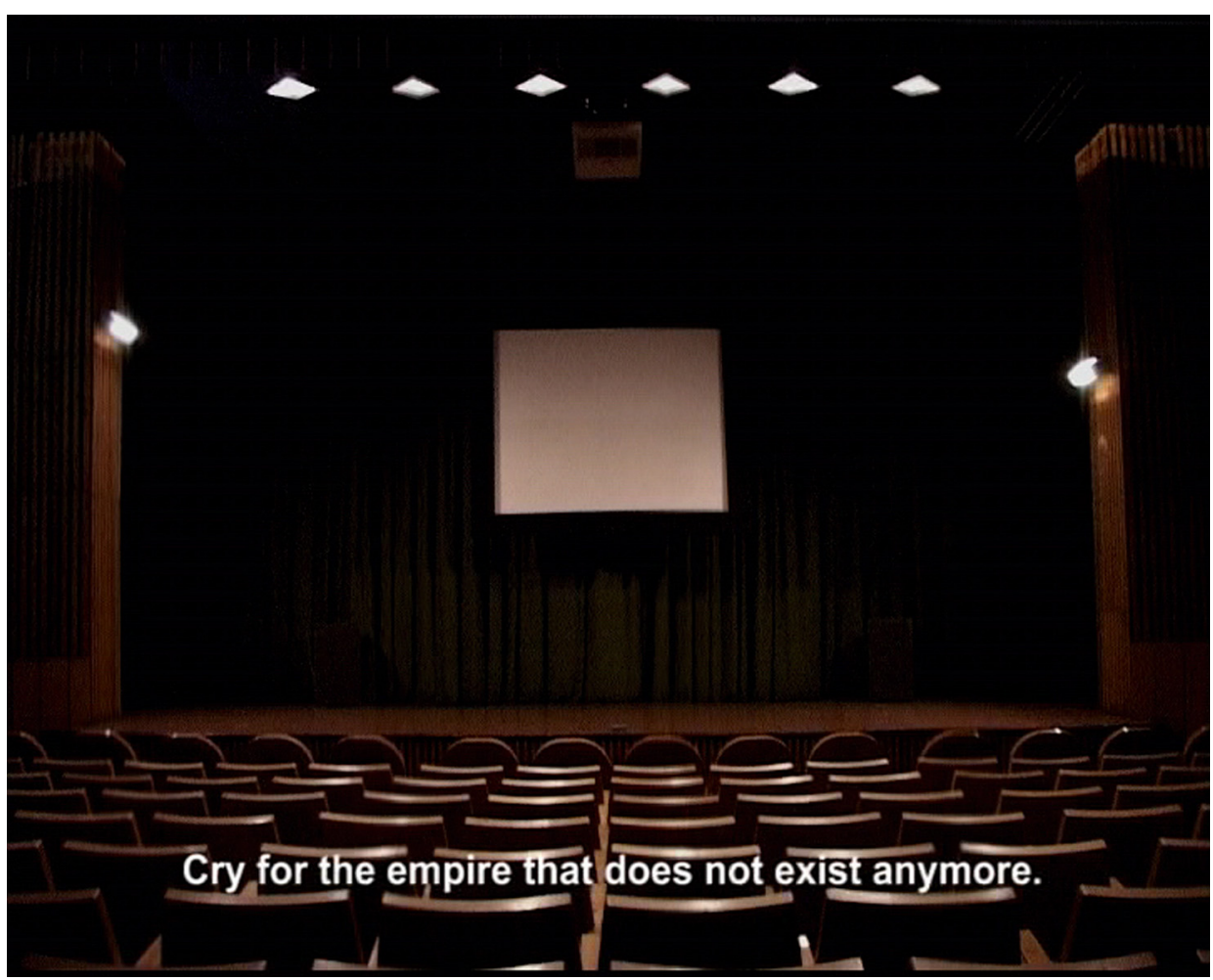

6 